\title{
Protocol Deviation Start Date
}

National Cancer Institute

\section{Source}

National Cancer Institute. Protocol Deviation Start Date. NCI Thesaurus. Code C83126.

The date on which the protocol deviation begins. 